Bruce D. Weinberg

earned his PhD at MIT and is associate professor of marketing and e-commerce at Bentley College.

Christine B. Williams earned her PhD at Indiana University and is professor of government at Bentley College.

Keywords: hybrid online-offline community, politics, campaign, e2f

\section{The 2004 US Presidential campaign: Impact of hybrid offline and online 'meetup' communities}

\author{
Bruce Weinberg and Christine Williams \\ Received (in revised form): 24 April 2006
}

\begin{abstract}
In his run for the 2004 Democratic Party presidential nomination, Howard Dean demonstrated the potential of a new type of hybrid online-offline community-building phenomenon, Meetup.com. It facilitates the process of consumers/citizens with similar interests on almost any topic, not just marketing or politics — finding each other and organising online so that they can get together as a group or 'meet up' offline. The authors classify this type of group as an e2f (electronic-to-face) community. In a study of 820 people who attended meetups (ie Meetup events) for presidential candidates between 22 January and 10 March 2004, meetup attendance was found to be positively related to important marketing measures of campaign effectiveness, such as donations, volunteering and candidate support and advocacy.
\end{abstract}

\section{Introduction}

In his run for the 2004 Democratic Party presidential nomination, Howard Dean demonstrated the potential of a new type of hybrid online-offline community-building phenomenon, Meetup.com. It facilitates the process of people with similar interests - on almost any topic, not just marketing or politics - finding each other and organising online so that they can get together as a group or 'meet up' offline. For Howard Dean, the use of Meetup.com was, along with other innovative online marketing vehicles such as blogs, at the heart of his campaign strategy, ${ }^{1}$ which effectively utilised the internet to attract and activate customers (ie supporters), organise marketing/campaign activities, communicate his message and raise money. In less than one year he went from political unknown to front-runner, appearing on the cover of Time magazine in August 2003. ${ }^{2}$ Along the way, he empowered hundreds of thousands of consumers/ citizens to participate in the political process, many for the first time, through community 'meetups' which involved organising online and meeting offline/face to face.

Although Howard Dean popularised Meetup.com, he was not the only candidate (ie in essence, political marketing organisation) to use it. Indeed, more than 130,000 supporters were signed up to participate in 'Kerry in 2004' meetups before the general election; and more than onehalf of these participants joined after his de facto nomination early in the 


\section{An e2f community}

\section{Meetup.com}

primary process. The authors believe that Howard Dean's innovative use of the internet for political organising in the 2004 presidential campaign is on par with Kennedy's ground-breaking use of network television advertising during the 1960 campaign against Nixon, and with Clinton's innovative use of cable television advertising in the 1992 campaign against Bush and Perot. Further, meetups, or a meetup-like process, will now probably be a key element in future presidential nomination processes and campaign strategies.

Meetup.com provides a means for creating a different type of community that is neither exclusively online nor exclusively offline. It is a hybrid people- and technology-based phenomenon, classified here as an 'electronic-to-face' (e2f) community. From a marketing perspective it incorporates key strengths of the internet, such as searching, finding and bringing together, ${ }^{3-6}$ and key strengths of 'traditional' face-to-face communities, such as commitment, strength, accountability and actionability. $^{7-10}$

This paper examines the relationship between meetup-related processes and 2004 US presidential marketing/campaign activities, including attracting customers/participants/volunteers, activism, organising and fundraising. In addition, it describes a new segment/type of consumer/ political activist and contrasts it with a more 'traditional' campaign activist. The data and analyses are drawn from a national electronic survey of participants in presidential meetup events.

This section ends with a brief introduction of Meetup.com. The next section reviews relevant literature on communities as they relate to the meetup process, and briefly explains how meetup-based communities are distinct from other types of e $2 \mathrm{f}$ communities, such as Match.com. Next the paper describes the methodology and highlights important findings with respect to meetups and marketing/political campaigns, including a comparison of those who participated in a meetup and then joined the campaign versus those who followed a more 'traditional' path of joining a campaign and then participating in a meetup. Finally, it discusses opportunities for future research and speculates about the future and evolution of Meetup.com, the meetup process and e $2 \mathrm{f}$ communities.

\section{About Meetup.com}

Meetup.com was partly inspired by Robert Putnam's book Bowling Alone and was founded in 2003 to help 'people find others who share their interest or cause and form lasting, influential, local community groups that regularly meet face-to-face'. ${ }^{11}$ Meetup events are held throughout the world, including the USA, UK, India and Australia. A broad variety of categories for meetups (ie meetup-related get-togethers) exist, including knitting, cooking, baseball, photography, advertising, Goth, etc. Meetup topics are created by users. The general process for participating in a meetup is to search for a topic of interest at the Meetup website and then enroll online for a meetup on a specific time and date at a particular location (eg a restaurant, coffee shop, pub, church basement - either Meetup.com or the 'organiser' of a meetup arranges for the use of a meeting place). Meetup.com's investors and board of directors include 


\section{Virtual communities}

highly respected experts such as Esther Dyson, Pierre Omidyar (founder of eBay) and (former) US senator Bill Bradley.

\section{Literature review}

Virtual communities have been defined as social aggregations that 'emerge from the Net when enough people carry on those public discussions long enough, with sufficient human feeling, to form webs of personal relationships in cyberspace'. ${ }^{12}$ These relationships may have started offline (eg high-school graduating cohort or friends) and the internet may have been used to supplement them; ${ }^{13}$ or they may have initiated online with interactions occurring online ${ }^{14}$ or, now, as in the case of Meetup, initiated online with interactions offline.

Marketing and other social scientists have framed online communities and processes in a number of ways, ${ }^{15}$ such as electronic organising, ${ }^{16}$ cyberactivism ${ }^{17}$ and e-advocacy. ${ }^{18}$ Further, Kozinets identifies five basic structural types of online communities: bulletin boards, webpages and webrings, listservs, multiuser dungeons and chatrooms. ${ }^{19}$ While Meetup is certainly online and could be classified as one of these basic types, it is distinct in that it includes a prominent offline dimension in addition to its online website technology. Meetup describes its simultaneous online and offline nature as 'an advanced technology platform and global network of local venues that helps people self-organize local group gatherings'.

At the present time, communities have been classified as being either online or offline, but Meetup does not neatly fall into one of these categories. Taking a cue from marketers, who at one time viewed online and offline marketing as separate and at odds but now view them cohesively and as part of an integrated ${ }^{20}$ or multichannel marketing effort, ${ }^{21}$ the authors classify Meetup as an organising tool for a new type of hybrid structural community: one that is integrated and neither exclusively offline nor exclusively online, and is thus an e $2 \mathrm{f}$ community.

Scholars have recognised the benefits of online communities, ${ }^{22}$ for example, bonding without being in close proximity either spatially or temporally, evolving across national borders and time zones, including all types of individuals, accommodating more people, possessing stronger memory and exploring new relationships or new identities. ${ }^{23}$ They also recognise the importance of 'the tie between traditional community practice and online community practice', and the need for a 'connection in the physical world'. ${ }^{24}$

The hold of an online community may be relatively tenuous given the relative ease with which one can withdraw, ${ }^{25}$ and online connections may not be as strong as those made face to face. ${ }^{26}$ Offline or face-to-face communities can be more effective with respect to taking action as, for example, they better facilitate identifying participants and holding them accountable. ${ }^{27}$

Some have argued that communities which are based on a combination of people and machines, in essence offline and online, are more effective than strictly computer-mediated communities ${ }^{28}$ and could result in greater participation ${ }^{29}$ and a greater sense of belonging. ${ }^{30}$ Others have put forth 


\section{Other e2f communities}

\section{Survey data}

that internet-based technologies are changing the way that advocacy and activism is practised with respect to the application of political campaigns, in that they make many aspects of lobbying, campaigning and organising more effective and efficient. ${ }^{31}$ But there is a need for research to address these issues empirically. ${ }^{32}$

This research on Meetup addresses this need and, with respect to political campaigns, looks (empirically) at it in terms of campaigning, organising and activism. It is expected that $\mathrm{e} 2 \mathrm{f}$ community meetups will be found to be positively related to campaigns and activism with respect to contributions, volunteering and candidate support.

The term e $2 \mathrm{f}$ is introduced to describe the type of community that is facilitated by Meetup, as the internet/web ('e') is used by community members to find each other and organise a meeting to be held in person, face to face (' $\mathrm{f}$ '). While this terminology for a type of community is new, other e2f communities have preceded those enabled by Meetup. For example, Match.com is an online dating/matchmaking service that helps people find each other online to get together (for dating) offline. Organisations have also used online sign-up and forums as precursors for annual special 'face-to-face' events (among customers), eg Harley Davidson ride 'experiences'. But Meetup-facilitated e2f communities are distinct in that they include groups of (more than two) people getting together on a regular, continuous basis, eg monthly or weekly (as opposed to annually). In addition, Meetup is different from what could be called face-to-electronic (f2e) community-based websites which facilitate an online 'reconnecting' of people who first got to know each other in person, eg Classmates.com, Reunion.com and FriendsReunited.co.uk which help bring together people who went to school or worked together.

\section{Methodology}

The data are from a national electronic survey of participants in presidential meetups. A survey was conducted of attendees at all presidential candidates' meetups between 22 January and 10 March 2004. Meetup.com included an invitation to participate together with the electronic survey's URL and link in follow-up e-mails it routinely sends to all (presidential) candidate meetup attendees the day after each event. The final sample had 820 valid responses from 422 Howard Dean meetup attendees, 170 John Kerry attendees, 102 Wesley Clark attendees, 60 Dennis Kucinich attendees, 51 John Edwards attendees, eight attendees from other candidates and seven who did not indicate whose they attended. They represented 49 states (there was none from South Dakota) plus the District of Columbia.

The electronic survey used Perseus Survey Solutions XP (5.0) software. It had 38 substantive questions and five identifiers for the respondent, candidate, location, month and prior attendance. Of the 38 substantive questions for respondents, 19 asked about their meetup experiences, 12 asked about their political activities and preferences and seven asked for their demographic characteristics. 


\section{Research questions}

\section{Results and findings}

This paper is concerned with two main research questions. First, is there a significant relationship between meetups and important campaign indicators? The study examined several traditional indicators of political effectiveness, namely campaign contributions, volunteering and candidate support. In addition, it investigated the relationship between meetup attendance and respondents' evaluation of Meetup and their willingness to become an advocate for the candidate (another indicator of campaign effectiveness).

Second, the study looked at activism. Is meetup attendance related to the degree of activism? And are those who first used Meetup and then joined the campaign different from those who first joined the campaign and then used Meetup? The former, termed 'Meetup activists first', if different from the latter, could be considered a new segment/type of activist.

\section{Sample characteristics}

The sample of meetup attendees can be described as mostly white, middle-aged, middle-income professionals, with more females than males (see Table 1). They were very active politically. They almost always voted, and a high percentage reported that they had volunteered and made campaign contributions in past elections. Almost all indicated that they used the internet several times a day, and more than half had visited several candidates' websites as well as multiple political activism websites.

\section{Campaign effectiveness}

Meetup was examined as a campaign tool along three traditional dimensions (of political activism): contributions, volunteering and candidate support. The relationship between campaign contribution amount and number of meetup events attended was statistically significant $(\mathrm{F}=26.304, p=0.000)$, with the mean contribution increasing with the number of meetups attended (Table 2). Similarly, the likelihood of volunteering was positively related to the number of meetups attended $(\mathrm{F}=13.235, p=0.000)-$ see Table 3 . Finally, the change in support for the candidate was significantly related to the number of meetup events attended ( $\mathrm{F}=7.285, p=0.000)$, as change in (positive) support increased with the number of meetup events attended (Table 4).

Given a status quo that meetup attendance is unrelated to key campaign

Table 1: Demographics for Meetup study and US population (2004)

\begin{tabular}{|lllcc|}
\hline & Age & Income & $\begin{array}{c}\text { Sex } \\
\text { Female/male } \%\end{array}$ & $\begin{array}{c}\text { Race } \\
\text { White/black } \%\end{array}$ \\
\hline Meetup study & 47 & $\$ 53,844$ & $60.3 / 39.7$ & $88.7 / 2.1$ \\
US population & $45^{*}$ & $\$ 44,389$ & $50.7 / 49.3$ & $77.1 / 12.9$ \\
\hline
\end{tabular}

* Median age among those 15 and older 
Table 2: Meetup attendance and campaign donations

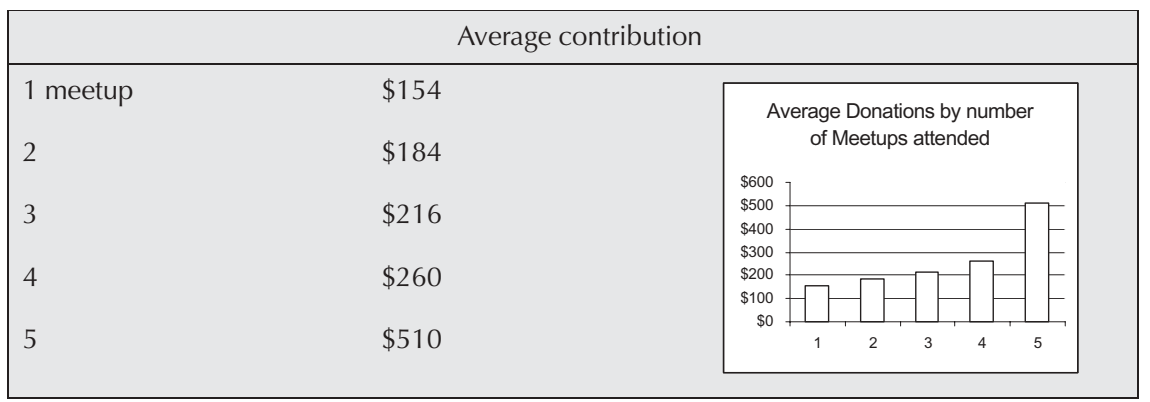

Table 3: Meetup attendance and volunteering

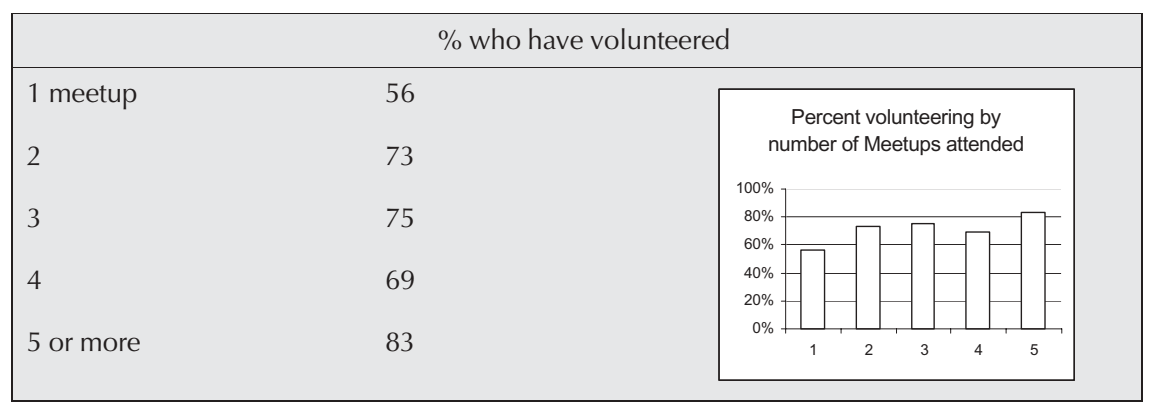

Table 4: Meetup attendance and candidate support

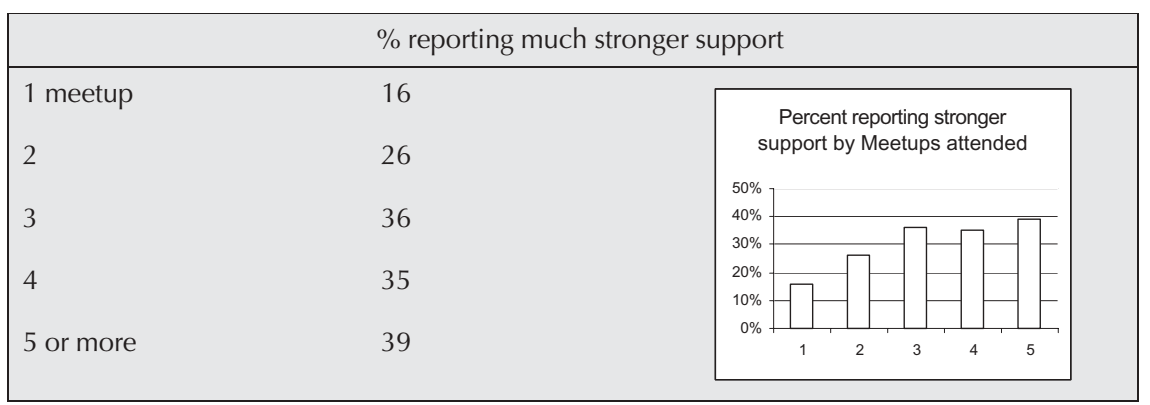

elements of donations, volunteering and candidate support, these results are initial indicators of Meetup's potential role as a campaign tool. It may behoove a political campaign to encourage voters and supporters to attend meetups, as increased Meetup usage is related to increases in donations, volunteering and support.

\section{Consumer experience}

The study was also interested in the relationship between the number of meetup events attended and consumer evaluations of Meetup with respect to a candidate's campaign. Respondents indicated the usefulness of a (candidate's) meetup event, whether they would spread positive word of mouth about the (candidate's) meetup event and the extent to which the 


\section{The Meetup experience and one's path of campaign involvement}

meetup event made them feel like they were a part of the candidate's campaign (all measures were five-point Likert scale items ranging from strongly agree to strongly disagree).

The relationship between the number of meetup events attended and the usefulness of Meetup was statistically significant $(\mathrm{F}=13.460, p=$ 0.000 ); usefulness increased with the number of meetups attended. The relationship between the number of meetup events attended and the type of word of mouth one would spread about Meetup was statistically significant $(\mathrm{F}=12.416, p=0.000)$; where word of mouth was increasingly positive as the number of meetups attended increased. And the degree to which one felt like part of the campaign was significantly related to the number of meetup events attended $(\mathrm{F}=16.271, p=0.000)$; the greater the number of meetups attended, the greater the extent to which one felt like part of the campaign (Table 5).

The study also compared the Meetup experience with respect to one's 'path of campaign involvement'. People are classified as a 'campaign activist first' if they were first involved in a campaign and then attended a meetup, and as a 'Meetup activist first' if they first attended a meetup and then got involved in a campaign (the word 'first' is dropped from the titles as a matter of convenience for the remainder of this paper). Meetup activists found meetups more useful $(\mathrm{F}=10.401, p=0.001)$, were more likely to spread positive word of mouth $(\mathrm{F}=10.805, p=0.001)$ and felt more involved in the campaign $(\mathrm{F}=14.427, p=0.000)$ - see Table 6.

\section{Advocacy}

Another important indicator to inspect was the relationship between consumers'/attendees' meetup attendance and their purchase-related actions, ie persuading/converting others (customer advocacy) or strengthening their own intentions. Four questions addressed the extent to which respondents were activated (for the candidate) as a result of their Meetup experience: the extent to which they would encourage others to learn more about the candidate, encourage others to work for the

Table 5: Meetup attendance and consumer experience*

\begin{tabular}{|lccc|}
\hline $\begin{array}{l}\text { Number of meetups } \\
\text { attended }\end{array}$ & $\begin{array}{c}\text { Meetup is } \\
\text { useful (\%) }\end{array}$ & $\begin{array}{c}\text { Will say positive } \\
\text { things about meetup (\%) }\end{array}$ & $\begin{array}{c}\text { Meetup event made } \\
\text { them feel like part of } \\
\text { campaign (\%) }\end{array}$ \\
\hline $\begin{array}{l}\text { First meetup } \\
\text { Five or more }\end{array}$ & 37 & 45 & 43 \\
\hline
\end{tabular}

$* \%$ responding strongly agree

Table 6: Activist type and consumer experience*

\begin{tabular}{|lccc|}
\hline Type of activist & $\begin{array}{c}\text { Meetup is } \\
\text { useful (\%) }\end{array}$ & $\begin{array}{c}\text { Will say positive } \\
\text { things about meetup (\%) }\end{array}$ & $\begin{array}{c}\text { Meetup event made } \\
\text { them feel like part of } \\
\text { campaign (\%) }\end{array}$ \\
\hline $\begin{array}{l}\text { Campaign } \\
\text { Meetup }\end{array}$ & 51 & 58 & 60 \\
\hline
\end{tabular}

*\% responding strongly agree 
candidate, encourage others to vote for the candidate and whether they would vote for this candidate (in their state's primary or caucus).

The results indicate a positive relationship between meetup attendance and the likelihood of: encouraging others to learn more about the candidate $(\mathrm{F}=3.842, p=0.004)$, encouraging others to work for the candidate $(\mathrm{F}=7.119, p=0.000)$, encouraging others to vote for the candidate $(\mathrm{F}=3.460, p=0.008)$ and (the meetup attendee her/himself) voting for the candidate $(\mathrm{F}=2.626, p=0.034)$ - see Table 7 .

The positive correlation between meetup attendance and advocating to others to work for the candidate suggests that frequent meetup attendees may be more likely to become grassroots recruiters for the campaign. This could explain one of the sources of Howard Dean's successful use of meetups: regular attendees may have felt empowered to recruit others to meetups and to the Dean campaign.

When campaign activists were compared to Meetup activists, the differences were non-significant except with respect to encouraging others to work for the candidate $(\mathrm{F}=6.006$,

$p=0.015$ ), where campaign activists were more likely to do so (Table 8). On the one hand it is not surprising that those who joined the campaign first would be more likely to go out and try to get others to join the campaign, as recruiting more volunteers, which would be considered a traditional political activity, is not as ingrained in Meetup activists. On the other hand it is interesting to note that those who came into the campaign via Meetup were just as vigorous with respect to encouraging others to learn about and vote for the candidate, and voting for the candidate themselves.

\section{Activism}

As mentioned earlier, three key dimensions of traditional political activism are (frequency of) voting, (extent of) volunteering and contributing (money). In the past few years the web has enabled new

Table 7: Meetup attendance and advocacy*

\begin{tabular}{|lcccc|}
\hline $\begin{array}{l}\text { Number of } \\
\text { meetups } \\
\text { attended }\end{array}$ & $\begin{array}{c}\text { Advocate others to } \\
\text { learn more about } \\
\text { candidate }(\%)\end{array}$ & $\begin{array}{c}\text { Advocate others to } \\
\text { work for candidate } \\
(\%)\end{array}$ & $\begin{array}{c}\text { Advocate others to } \\
\text { vote for candidate } \\
(\%)\end{array}$ & $\begin{array}{c}\text { Will vote for } \\
\text { candidate }(\%)\end{array}$ \\
\hline $\begin{array}{l}\text { First meetup } \\
\text { Five or more }\end{array}$ & 74 & 51 & 71 & 85 \\
\hline
\end{tabular}

$* \%$ responding strongly agree

Table 8: Activist type and advocacy*

\begin{tabular}{|lcccc|}
\hline $\begin{array}{l}\text { Type of } \\
\text { activist }\end{array}$ & $\begin{array}{c}\text { Advocate others to } \\
\text { learn more about } \\
\text { candidate }(\%)\end{array}$ & $\begin{array}{c}\text { Advocate others to } \\
\text { work for candidate } \\
(\%)\end{array}$ & $\begin{array}{c}\text { Advocate others to } \\
\text { vote for candidate } \\
(\%)\end{array}$ & $\begin{array}{c}\text { Will vote for } \\
\text { candidate }(\%)\end{array}$ \\
\hline $\begin{array}{l}\text { Campaign } \\
\text { Meetup }\end{array}$ & 81 & 69 & 79 & 89 \\
\hline
\end{tabular}

*\% responding strongly agree 


\section{Activism}

forms of political activism: visiting political websites became relatively frequent during the 2000 US presidential campaign; donating online became significant during the 2004 campaign (eg Howard Dean raised tens of millions of dollars online); and visiting political activism websites (eg MoveOn.org) also became popular during the 2004 campaign. Given this, three indices were formed: a traditional activism index, based on the degree to which one performed 'traditional' activism (ie frequency of voting, extent of volunteering and monetary contributions), an online activism index, based on the degree to which a consumer performed 'new/online' activism (ie donating online, extent of visiting campaign websites and extent of visiting political activism websites) and total activism index, which is the sum of the traditional activism index and the online activism index.

The study assessed the relationships between meetup attendance and political activism, and between activist type (ie 'campaign first' or 'Meetup first') and political activism. To test the relationship between Meetup activism and other kinds of political participation, a summated index of political activism was constructed. A positive and statistically significant relationship was found between meetup attendance and the traditional activism index $(\mathrm{F}=22.125, p=0.000)$, the online activism index $(\mathrm{F}=11.460, p=0.000)$ and then, of course, the total activism index $(\mathrm{F}=17.852, p=0.000)$; see Table 9. The direction of these findings is what one would expect if Meetup represented a different form of political activity.

Campaign activists had a higher mean traditional activism index $(\mathrm{F}=4.138, p=0.042)$ and a higher mean total activism index $(\mathrm{F}=$ $3.931, p=0.048$ ), while the difference on the online activism index was non-significant $(\mathrm{F}=0.851, p=0.357)$ - see Table 10. It is not surprising that campaign activists had a higher mean score on the traditional activism index, but one might expect that Meetup activists would score higher on the online activism index given that Meetup does have an online component. Perhaps because Meetup has both an online component (ie the 'e', electronic, of this e2f community) and an offline component (ie the ' $\mathrm{f}$ ', face, of this e $2 \mathrm{f}$ community) there may be a

Table 9: Meetup attendance and activism

\begin{tabular}{|lccc|}
\hline $\begin{array}{l}\text { Number of meetups } \\
\text { attended }\end{array}$ & $\begin{array}{c}\text { Total activism index } \\
\text { score }\end{array}$ & $\begin{array}{c}\text { Online activism index } \\
\text { score }\end{array}$ & $\begin{array}{c}\text { Traditional activism } \\
\text { index score }\end{array}$ \\
\hline First meetup & 9.80 & 4.21 & 5.59 \\
Five or more & 12.06 & 4.64 & 7.42 \\
\hline
\end{tabular}

Table 10: Activist type and activism

\begin{tabular}{|lccc|}
\hline Type of activist & $\begin{array}{c}\text { Total activism index } \\
\text { score }\end{array}$ & $\begin{array}{c}\text { Online activism index } \\
\text { score }\end{array}$ & $\begin{array}{c}\text { Traditional activism } \\
\text { index score }\end{array}$ \\
\hline Campaign activist & 11.47 & 4.54 & 6.93 \\
Meetup activist & 11.01 & 4.49 & 6.52 \\
\hline
\end{tabular}


balance in online and offline inclinations among those who use it. On the other hand, it could be argued that 'online' is an 'equaliser' for Meetup activists in that they are 'behind' with respect to traditional activism activities. Perhaps the greater awareness and access to online political activism vehicles/tools plays a role in this.

\section{Summary and future research}

This paper introduces the notion of an e $2 \mathrm{f}$ community and reports on the use of meetups, an e2f community-based activity, in the 2004 US presidential campaign. It was found that Meetup usage was positively related to contributions, volunteering, support for a candidate (ie the product) and (the likelihood of) serving as an advocate for the campaign (eg by encouraging others to learn about, work for or vote for the candidate).

The study also looked at what could be considered a new segment of activist, termed Meetup activists (first). In most respects they were similar to the 'traditional' campaign activists. They were equivalent with respect to advocating others to learn about and vote for the candidate, and in (themselves) voting for the candidate; but they were not as likely to advocate others to work for the candidate. Nevertheless, this could be interpreted to suggest that Meetup may be a useful vehicle for acquiring 'attractive' customers, which, in this application, was bringing new people into the political process for a campaign.

For future research it would be interesting to study other types of

\section{Future research} hybrid online-offline communities, assess their role with respect to marketing and customer relationships and evaluate their impact with respect to marketing performance. For example, when and for which types of marketing objectives are e $2 \mathrm{f}$ communities most likely to be effective, and when and for which types of marketing objectives are f2e (ie face-to-electronic) communities most likely to be effective? In addition, exploration into emerging types of hybrid communities would be interesting, for example TheFaceBook.com, which is becoming extremely popular on college campuses throughout the USA and enables students on the same (or different) college and university campuses, who see each other offline, to learn more about each other online and to interact offline - perhaps this could be considered an f2e $2 \mathrm{f}$ type of community. (In addition, TheFaceBook recently secured funding in excess of $\$ 12 \mathrm{~m}$ from Accel Partners and the founder of Paypal.) Finally, hybrid communities in the business-to-business domain should also be studied, eg see LinkedIn.com, which is a 'networking tool that helps you discover inside connections to recommended job candidates, industry experts and business partners'.

From a practical perspective, there is great potential for commercial e2f applications by organisations which view markets through an e $2 \mathrm{f}$ lens. A key is integrating current and evolving technologies that can enhance socialised electronic coordination (eg finding consumers/people, stimulating word of web ${ }^{33}$ ), such as GPS/location identification, RFID, $4 \mathrm{G}$ wireless communication and personal profile systems, with problems or contexts where success is related to socialised physical action (eg 
visiting a store, consuming a product, banding together to build a homeless shelter, distributing a vaccine to an underdeveloped population).

For example, an e2f marketing communications campaign to generate awareness, and ultimately sales, for a new (yet to be released) movie could operate as follows. A person profile system/database containing marketing-relevant information about individuals is searched for a set of 'seed' consumers who would be, potentially, effective opinion/grassroots leaders. These consumers, who have opted in to participate, are sent a marketing communication about the new movie (eg a short promotional clip/segment), which they retrieve via a hand-held mobile device. They earn 'points' in some type of reward system (eg prizes, products, social status as an expert product reviewer and recommender) for 'effective' communication/organisation activities that, in the case of this example, increase awareness and sales, such as getting another 'conquest' consumer to view the movie clip or to buy a movie ticket. (Technology enables recording and tracking of these behaviours.) In addition, an individual earns bonus points for each 'conquest' consumer who views the movie during a 'similar' time frame (in any theatre location) or at the same time in the same movie theatre! (Again, technology, eg GPS or RFID, would make it possible to identify these behaviours.)

Naturally, other mechanisms for augmenting this e2f application could be devised and considered, eg consumers could also earn points for 'effective' activities carried out by each 'conquest' consumer obtained. Nevertheless, the authors hope that this example provides guidance and encourages marketers to leverage technology that can be effective in integrating socialised (electronic) coordination with socialised physical action and develop e $2 \mathrm{f}$ applications that can add value to their organisation.

\section{References}

1. Gownder, J. P. (2003) 'An online revolution? I don’t see it', Washington Post, 6 July, p. B1.

2. Tumulty, K. (2003) 'The Dean factor: He's got money, momentum, excitement. But is that enough to take him to the top?', Time, 11 August.

3. Brewer, E. A. (2001) 'When everything is searchable', Communications of the ACM, Vol. 44, No. 3, pp. 53-55.

4. Brewer, E. A. (2002) 'The consumer side of search', Communications of the ACM, Vol. 45, No. 9, pp. $40-41$.

5. Dreze, X. and Zufryden, F. (2004) 'Measurement of online visibility and its impact on internet traffic', Journal of Interactive Marketing, Vol. 18, No. 1, pp. 18-37.

6. Telang, R., Boatwright, P. and Mukhopadhay, T. (2004) 'A mixture model for internet searchengine visits', Journal of Marketing Research, Vol. 41, No. 2, pp. 208-214.

7. Bagozzi, R. P. and Dholakia, U. M. (2002) 'Intentional social action in virtual communities', Journal of Interactive Marketing, Vol. 16, No. 2, pp. 2-21.

8. Etzioni, A. and Etzioni, O. (1997) 'Communities: Virtual vs real', Science, No. 277, 18 July, p. 295.

9. Etzioni, A. and Etzioni, O. (1999) 'Face-to-face and computer-mediated communities: A comparative analysis', Information Society, Vol. 15, No. 4, pp. 241-248.

10. Hick, S. (2003) 'Community practice in the internet age', in Shera, Wes (ed.) Emerging Perspectives on Anti-oppressive Practice, Canadian Scholars’ Press Inc., Toronto. 
11. Putnam, R. (2000) Bowling Alone: The Collapse and Revival of American Community, Simon \& Schuster, New York, NY.

12. Rheingold, H. (1993) The Virtual Community: Homesteading on the Electronic Frontier, Addison-Wesley, Reading, MA, p. 5.

13. Wellman, B. and Milena G. (1999) 'Net-surfers don't ride alone: Virtual communities as communities', in Wellman, B. (ed.) Networks in the Global Village, Westview Press, Boulder, CO, pp. 331-366.

14. Hagel, J. III and Armstrong, A. G. (1997) Net Gains: Expanding Markets through Virtual Communities, Harvard Business School Press, Boston, MA.

15. Hick, ref. 10 above.

16. Wittig, M. A. and Schmitz, J. (1996) 'Electronic grassroots organizing', Journal of Social Issues, Vol. 52, No. 1, pp. 53-69.

17. Price, T. (2000) Cyberactivism: Advocacy Groups and the Internet, Foundation for Public Affairs, Washington, DC.

18. Bennett, D. and Feilding, P. P. (1999) The Net Effect: How Cyber-Advocacy Is Changing The Political Landscape, E-Advocate Press, Merrifield, VA.

19. Kozinets, R. V. (1999) 'E-tribalized marketing? The strategic implications of virtual communities of consumption', European Management Journal, Vol. 17, No. 3, pp. 252-264.

20. Iacobucci, D. and Calder, B. (2003) Kellogg on Integrated Marketing, John Wiley \& Sons, Hoboken, NJ.

21. Rangaswamy, A. and Van Bruggen, G. H. (2005) 'Opportunities and challenges in multichannel marketing: An introduction to the special issue', Journal of Interactive Marketing, Vol. 19, No. 2, pp. 5-11.

22. Bagozzi and Dholakia, ref. 7 above; Etzioni and Etzioni, ref. 8 above.

23. Etzioni and Etzioni, ibid.

24. Hick, ref. 10 above.

25. Bagozzi and Dholakia, ref. 7 above.

26. Hick, ref. 10 above.

27. Etzioni and Etzioni, ref. 8 above.

28. Etzioni and Etzioni, ref. 9 above.

29. Hampton, K. and Wellman, B. (2003) 'Neighboring in Netville: How the internet supports community and social capital in a wired suburb', City and Community, Vol. 2, No. 4, pp. 277-311.

30. Nip, J. Y. M. (2004) 'The relationship between online and offline communities: The case of the Queer Sisters', Media, Culture \& Society, Vol. 26, No. 3, pp. 409-428.

31. Hick, S and McNutt, J. (2002) 'Communities and advocacy on the internet: A conceptual framework', in Social Work Advocacy and Activism on the Internet, Lyceum Press, Chicago.

32. Hick, ref. 10 above.

33. Weinberg, B. D. and Davis, L. (2005) 'Exploring the WOW in online auctions', Journal of Business Research, Vol. 58, No. 11, pp. 1609-1621. 